\title{
Medicine is war: and other medical metaphors
}

\author{
PAUL HODGKIN
}

When I worked in a paediatric casualty department children were forever being told that after being stitched, $x$ rayed, or covered in plaster they would be "bionic." The desire to be more machine like is apparently widespread-inevitably perhaps, in an age when technology is both idolised and feared. Medicine is strewn with mechanistic language and concepts, and the metaphor "the body is a machine" suffuses much of the language of pathology and physiology. I write here about some of the linguistic forms that underlie the way we talk about medicine and the way that they limit as well as advance our thinking.

Examining the metaphors behind language is worth while because it clarifies our assumptions. Seeing the body as a machine, for example, has been useful-the heart, after all, is much like a pump and treating it as one has provided many insights. The success of the mechanistic approach, however, has meant that we have often imbued the body with other machine like attributes. All too easily patients become-like machines-identical, passive and "fixable." Medicine, as has often been pointed out, has become dominated by a mechanistic hubris, which sees machines and engineered solutions to ill health as the favourite way forward.

All this, of course, begs the question of the relation between the language we use and the things it describes. Some have felt that any language may actually prevent its native speakers from perceiving the world in ways that are quite "normal" in other tongues. According to this view, language more or less determines reality. A more orthodox position is that language and our perception of the world evolve together, both influencing each other. The particular vocabulary and syntax of any given language "do not make it impossible to express certain things, they merely make it more difficult to express them."

The vocabulary of medicine is certainly one example of the way linguistic forms affect our perception of the world. As Dixon has pointed out, we have 20 rubrics for different types of respiratory infection but only one word for poverty. ${ }^{3}$ Differentiating respiratory syncytial virus from mycoplasma thus becomes possible, but we still have only general terms with which to express, say, overcrowding. Our language thus drives important factors to the margins of consciousness.

\section{Most common themes}

Much medical language is built around a few metaphors. Phrases such as "He sank into a coma," "You're in tip top condition," and "Falling ill" are constructed round the idea that health is up and illness is down. (This particular example is taken from an excellent book by Lakoff and Johnson, ${ }^{+}$which describes in detail the importance of metaphors in organising our thoughts and language.)

That health is up is hardly surprising. We are after all up and about when well and horizontal when dead or ill. A meatier medical metaphor is "medicine is war." The language that we use about our role as doctors is cast almost entirely by this metaphor and military images also appear in every aspect of medical language and jargon:

It's an overwhelming infection; she's got an infiltrating carcinoma; the body's defences; he's having a heart attack; killer T cells; we must treat him aggressively and use everything in therapeutic armamentarium, we've wiped out smallpox; go to casualty and the house officer will deal with you;

Department of General Practice, University of Manchester PAUL HODGKIN, MB, CHB, lecturer

Correspondence to: 47 Collegiate Crescent, Sheffield S10 2BR.
A common variant of this is the "medicine is a detective story" metaphor, in which the disease is the villain and making the diagnosis approximates making the arrest:

This sinister disease requires a rigorous history to be taken plus a searching examination together with a high index of suspicion in order to spot the tell tale clues and make the correct diagnosis.

The Boy's Own Paper style is perhaps no accident since we talk, think, and write about doctors within a tradition that sees them almost exclusively as men.

The "medicine is war" metaphor also has more serious implications as it emphasises that taking action is a virtue, patients are passive, the main protagonists in this drama are doctors and diseases (patients are not the "real" focus), technologies are weapons (and thus, implicitly, the more the better), and we doctors know best as we are the ones in control. These attitudes clearly have some advantages - for example, it is easier for doctors to bear the failures of medicine if the "real" enemy is construed to be the disease. For many specialties, however, including geriatrics, psychiatry, and general practice, using the "medicine is war" metaphor can be counterproductive. In addition, the doctor's self image of battling against disease may not be in the patient's best interest. The cost of our inappropriately aggressive attitude to fighting disease has often been borne by our patients as they have suffered, among other things, tonsillectomy, hospital delivery, and the overprescription of psychotropic drugs.

\section{Roles of doctors, patients, and disease}

The concept that patients are in part just the "clinical material" with which doctors fight the great battle against disease takes subtle forms. The word cohort, for example, was originally part of a Roman battalion-a set of identical and ultimately expendable soldiers to be used to the most useful advantage in winning the battle.

Fighting wars is usually an unpleasant, boring, and masculine activity. The "medicine is war" metaphor perhaps encourages the virtues required to survive the long hours and intense hierarchies of hospital life. Unfortunately, it also discriminates against feeling and reflection and makes it harder to strike the right balance between work and personal life.

Another curious twist of medical language is the way that we habitually talk about diseases as if they were objects rather than processes, saying, for example, "He's got mumps" and not "He's mumping." Cassells pointed out how widely both patients and doctors view disease as an "it," with an independent existence." Thinking of diseases as objects comes so naturally to us that it is difficult to see how this view is anything but helpful and necessary. After all, this is the main way in which we have classified and studied illness. But to see disease as an object and not a process is to emphasise that one can indeed "get rid" of "it", that its arrival was probably unbidden and that cure is equivalent to physical removal. As patients we can draw tight comfortable lines around the disease and say that the rest is normal. For doctors the disease, rather than the context in which it occurs or its meaning for the patient, becomes the most important level of study. The corollary of the "diseases are objects" metaphor is that patients are naturally seen as containers for those objects:

He's full of cancer; we've just got to get in there and control the bleeding; I'm taking so many pills I'm beginning to rattle; we must get to the bottom of the problem.

Again this is widespread and useful because in many ways we are containers that we can physically put tablets into and take gall bladders out of. To the extent that patients are seen as mere vessels 
for disease, however, they will also be assumed to be passive and less important than the disease itself.

\section{Medicine and emotions}

There is one last, intriguing aspect of language that is relevant to medicine, which is the way in which we talk about emotions. Many of the phrases we use to talk about feelings depend on two assumptions: emotions are fluids and intensity is temperature.

He was swamped with feeling; she was bubbling over with joy; I nearly exploded with rage; they were boiling over with excitement; they've channelled their feelings into other things; he's emotionally volatile.

The language of feeling implies an extensive network of subterranean piping. The purpose of this subconscious plumbing is to prevent the unseemly spilling of emotions into the open, and indeed many of the phrases we use imply plumbing failures of one kind or another. If we do, heaven forbid, actually begin to feel something all kinds of ills apparently lie in wait. The emotional fluids may even vaporise under the heat of our feelings and end up clouding our judgment. Within medicine, at least, emotions and feelings are actually thought of as dangerous and contaminating fluids.

The traditional way of dealing with this problem is by trying to keep the emotional temperature as low as possible. Exactly how this is to be achieved is rarely explained but it is certainly the method implicitly recommended in most teaching on medical and surgical wards. Apparently the mature doctor should be able to control the emotional temperature of even the most tragic situations so that at least his or her feelings remain nicely controllable as frigid blocks of ice. Such assumptions, of course, do little to help patients-or for that matter doctors.

The metaphors described in this article are pervasive and form the basis of many of our concepts about medicine. They are often used among patients too, and form the normal, common sense way of thinking and talking about ill health and doctors.

Problems arise not because these ways of thinking are not valid - at times all these metaphors are useful - but because their pervasiveness excludes other equally true ways of seeing health and illness. The metaphors underlying our language create a subtle pressure that is perhaps part of the reason that we find it so difficult to think of people as wholes, as having a reality much greater than the sum of their organs, diseases, or economic, value. Having such a restricted choice of language we are all too often forced, inadvertently, into useless, harmful, or insensitive ways of thinking.

\section{Alternative metaphors}

It is, of course, possible to try to create new metaphors with which to weave a richer understanding of both illness and disease but this is not easy. The old metaphors are hard to dislodge, while new ones inevitably seem precocious.

Still, it is interesting to see what other metaphors might be available and the kinds of thinking they imply. An alternative to "medicine is war," for example, might be "medicine is a collaborative exploration." This recognises that what we are engaged on is exploratory-by its nature it is intrinsically uncertain. Although some people may have more expertise in particular aspects of medicine than others, neither doctors nor patients have a direct line to the truth.

It also implies that medicine is cooperative and many people are involved: patients, their family, health workers, and researchers. Success depends on working together. Neither success nor failure is the sole responsibility of any one person; in other words, it is not the surgeon alone who "cured" the patient but just as importantly the patient's own ability to heal himself together with the other members of staff, family, and so on. Embedded in the metaphor too, is "labour," reminding us that medicine depends on hard work by both patient and doctor.

Our bodies often replace almost all of their physical constituents. Metaphors such as "the body is an enduring pattern" or "the body is a biochemical dance" might profitably supplement the currently overwhelming view of bodies as machines. ${ }^{6}$ These metaphors are just as true as a mechanistic way of looking at physiology but would emphasise, for example, the processes of keeping healthy and the importance of nutrition. They assert our vitality and the shimmering complexity of living processes rather than the predictability of the machine.

There are many other subjects that might yield additional new metaphors and insights. We could, for example, reacquaint ourselves with the word healing and all the many meanings that it has for both lay people and alternative practitioners. There is also a widespread lay metaphor "illness is imbalance." This is little used by doctors but might form the basis on which some of the insights of modern medicine might be reconstructed for both patients and doctors. New scientific understandings are themselves a potent source of new metaphors. The image of the hologram, which influences current research in neurophysiology, is an example of a new metaphor that emphasises the wholeness and interrelationship of organisms.

Finally, there is the fact that medicine has grown out of a science governed and dominated by men and masculine patterns of thought. ${ }^{8}$ Control of emotions and the pursuit of power are prized in this atmosphere. With the rising awareness that an excessively masculine style of science has had considerable costs as well as benefits for humanity comes the possibility of other more complete ways of proceeding. Perhaps we could learn a lot from a medicine less dominated by men.

If we are to humanise medicine and create institutions that encourage the full participation of patients, while offering them the best of traditional medicine, we need to incorporate new images into our thinking. Essential to this process would be new metaphors around which we can reconstrue both our present and our emerging knowledge. In the face of the further drive to reductionism that will flow from bioengineering such unifying and believable metaphors will be essential if we are to continue in any way to be healers as well as technocrats.

\section{References}

1 Whorf B. Language, thought and reality. New York: Wiley, 1956:207-19.

2 Brown R. In: Henle P, Arbour A, eds. Language, thought and culture. Michigan: University of Michigan, 1972:10-11

3 Dixon AS. Family medicine-at a loss for words. $\mathcal{J}$ R Coll Gen Pract 1983;33:358-63.

4 Lakoff G, Johnson M. Metaphors we live by. Chicago: Chicago University Press, 1980

5 Cassells EJ. Disease as an "it." Soc Sci Med 1976;10:143-6.

6 Dossey L. Space, time \& medicine. Boulder, Colorado: Shambhala Publications, 1982:73-4

7 Pribham K. In: Wilber K, ed. The holographic paradigm and other paradoxes. Boulder, Colorado: Shambhala Publications, 1982:27-34

8 Easlea B. Science and sexual oppression. London: Weidenfeld and Nicolson, 1981.

\section{Friday 13 - a day to avoid?}

From the witch doctors of the South Pacific to the faith healers of contemporary society superstition and medicine seem to have been inextricably linked. For the most part beliefs in superstition are personal and idiosyncratic, little affecting the everyday practice of medicine. In the past year, however, it has been noticed that the superstition that Friday 13 is a day connected with bad luck ${ }^{12}$ has led to many patients refusing to have operations performed on this day. We set out to see if there was any truth in the superstition.

The total daily attendance at this hospital of patients sustaining injury on each Friday 13 between 1975 and 1985 was recorded, and the number of new attendances on the preceding Friday - that is, Friday 6-was also recorded. The number of new accidents reported varied from 130 on 13 August 1976 to 280 on 6 October 1970. The mean attendance on Friday 13 was 196 (SD 39) and on Friday $6204(20)$. There was no significant difference between the attendances by Student's $t$ test. The results show that there is no evidence of an increased incidence of accidents on Friday 13. Although cynics may suggest that people are more circumspect on this day, and therefore less at risk, the evidence is that Friday 13 is just another day.-J A FAIRCLOUGH, $\mathbf{S} \mathbf{R}$ JOHNSON, D J SHEWRING, department of traumatic and orthopaedic surgery, Cardiff Royal Infirmary, Cardiff CF2 1SZ.

1 Leach M. Funk and W'agnall's standard dictionary of folklore, mythology, and legend. London: New English Library, 1975:425-6.

2 Waring P. A dictionary of omens and superstitions. London: Souvenir Press, 1978:97-8. 